\title{
Training Homeless Education Liaisons to Support the Academic Needs of Homeless Students
}

\author{
Vanessa Wood \\ University of Phoenix, United States \\ Marni Finkelstein (Corresponding author) \\ John Jay College of Criminal Justice, Adjunct Anthropology, United States \\ E-mail: mfinkelstein@jjay.cuny.edu
}

Received: August 15, 2019

doi:10.5296/jet.v7i1.15275
Accepted: September 2, 2019 Published: December 5, 2019

URL: http://dx.doi.org/10.5296/jet.v7i1.15275

\begin{abstract}
The purpose of the qualitative descriptive case study was to describe how homeless education liaisons use training and resources to support the academic success of homeless students. Semi-structured interviews were conducted with 15 local homeless education liaisons in Virginia to determine how they perceive and incorporate training and community resources to encourage the academic success of students experiencing homelessness. Research revealed that they training they received met liaison needs despite needed adaptations to address legislation changes. Implications for leadership are a need to allot necessary time for liaisons to meet needs of students through understanding liaison function and resource availability. Recommendations for assisting liaisons in meeting needs of students are made.
\end{abstract}

Keywords: Homeless Education, Liaison, Homeless Students, McKinney-Vento Homeless Assistance Act, Every Student Succeeds Act, Educational Training

\section{Introduction}

Homelessness is one of many issues influencing the success rate of American students in public schools (Masten, Fiat, Labella, \& Strack, 2015). In the United States, between 1.6 and 2 million minors experience homeless conditions nightly (Edidin, Ganim, Hunter, \& Karnik, 2012). Homeless students are considered children in crisis (Harper, Harper, \& Stills, 2003). Emotional issues are more prevalent in homeless individuals than those who are stably housed (Edidin et al., 2012; Masten et al., 2015). They experience more attention span issues, sleeping, and delayed speech problems, aggressiveness, withdrawal, and shyness than their housed peers (Masten et al.). They are also more prone to depression. This may increase the problem of student retention, and the inability to complete high school (Masten et al.; Rafferty \& Shin, 1991). 
In 1987, legislators formally addressed the issue of homeless students in federal law with the Stewart B. McKinney Homeless Assistance Act. Part of this Act created guidelines for how to assist students experiencing homelessness (Aviles de Bradley, 2008; Nix-Hodes \& Heybach, 2014). One primary purpose of this legislation was to remove obstacles homeless students face in pursuit of education, such as immunization and residency requirements, transportation issues, and access to school records during transient times (Rafferty \& Shinn, 1991). To provide students experiencing homelessness with an educational advocate, lawmakers created the position of local homeless education liaison, using the services of social workers and other school staff (Aviles de Bradley; Nix-Hodes \& Heybach). The role of the homeless education liaison is to help homeless students overcome obstacles of residency, vaccination requirements, and transportation, while on their way to academic success (Murphy \& Tobin, 2011). However, despite recent policies, there is a lack of knowledge regarding how local homeless education liaisons are trained, and how they use their training to address issues homeless students face (Pavlakis, 2014; Petersburg, 2010). Understanding what resources are available and how they are implemented could improve best practices for liaisons and state coordinators who are responsible for training liaisons (Jozefowicz-Simbeni \& Israel, 2006; Miller, 2011b; Murphy \& Tobin).

This article reports on findings from a research project that sought to explore how homeless education liaison utilized their training and community resources to support the academic success of homeless students. Through an analysis of narrative data that was collected from a group of homeless education liaisons, the finding revealed several themes including the perceptions that the liaisons had on their training, the adaptations they felt were needed to address legislative changes, and their utilization of available training resources.

\section{Literature Review}

Statistics on the growing homeless student population are bleak, indicating a homeless student population in the United States exceeding 1.3 million (U.S. Department of Education, 2015). For homeless students, school absences result in lower test scores and grades along with increased grade retention and dropout rates (Hendricks \& Barkley, 2011). When students' most basic needs of lack of safety, food or shelter are not met, motivating them to academic success may be difficult (Kislyakov, Shmeleva, Karaseva, \& Silaeva, 2014; Maslow, 2013). Feelings of inadequacy may manifest in poor academic performance, low attendance, or behavior problems, including aggressiveness (Miller, 2011a).

To address these issues, the Stewart B. McKinney Homeless Assistance Act was created to oversee how homeless students receive their education (Aviles de Bradley, 2008; Nix-Hodes $\&$ Heybach, 2014). With each evolution of the legislation, educational rights of students experiencing homelessness became more specific, from initially protecting rights of homeless students, to the development of the local homeless education liaison position (Every Student Succeeds Act (ESSA), 2015).

As part of their professional duties, liaisons are responsible for ensuring homeless students succeed in school and have access to services they are eligible for, including meals, gifted programs, and special education accommodations (Aviles de Bradley, 2008; McKinney-Vento 
Act, 2002; Nix-Hodes \& Heybach, 2014). Liaisons ensure McKinney-Vento legislation is enforced within school districts despite challenges, such as discrimination against students experiencing homelessness, or the denial of student access to appropriate educational resources (Aviles de Bradley; McKinney-Vento Act; Nix-Hodes \& Heybach). These front-line social workers are essential to ensuring the American educational system takes care of homeless students by serving as guides to students, their families, and school officials, while acting as the eyes and ears for state coordinators, who are responsible for collecting data on the student population (Project HOPE-Virginia, 2015).

However, there is evidence to suggest homeless education liaisons may not have full access to tools or training they need to meet their obligations (Masten et al., 2015). For educational liaisons to effectively encourage the academic success of students experiencing homelessness, they need to prioritize tasks, regardless of full-time or part-time status (NCHE, 2013). By setting agendas in the best interest of students, homeless educational liaisons can better meet demands of their positions (NCHE, 2013). They can be more productive and successful by building networks with designated officials in the community and within districts where they work (NCHE, 2013). By becoming familiar with legislation, such as the McKinney-Vento Act (2002), No Child Left Behind Act (2002), and Every Student Succeeds Act (ESSA) (2015), designed to assist homeless students, liaisons gain a stronger ability to meet duties of their professional capacities despite limited resources (NCHE, 2013).

The National Center for Homeless Education is the technical assistance center funded by the U.S. Department of Education (U.S. Department of Education, n.d.). Training objectives and materials provided by the National Center for Homeless Education (NCHE) are vital to liaison training. As the technical expert regarding student homelessness for the U.S. Department of Education, NCHE creates and publishes the Homeless Liaison Toolkit and other training as well as resource materials for education (U.S. Department of Education, n.d.). Writers designed the Homeless Liaison Toolkit as a comprehensive guide to assist liaisons to effectively implement the McKinney-Vento Act within their local education agency (U.S. Department of Education, n. d.).

Under provisions of ESSA, state-level coordinators are responsible for creating and monitoring the mandatory training and performance of local homeless education liaisons (ESSA, 2015). The coordinator is responsible for making training accessible for liaisons. In Virginia, the state coordinator's office is called Project HOPE-Virginia (William and Mary School of Education, 2016). Project HOPE-Virginia provides liaisons with access to the Local Homeless Education Liaison Toolkit, which is the primary professional guide for liaisons (William and Mary School of Education). The organization provides access to educational briefs offering liaisons other essential information, such as how to most effectively perform their jobs, ideas on how to network, as well as suggestions for implementing the McKinney-Vento Act (William and Mary School of Education).

The plethora of risk factors encountered by homeless students decreases their chances of graduation and academic success (Aviles de Bradley, 2011; Masten et al., 2015; Miller, 2015). To compound the situation, children and youth cannot receive needed assistance without being properly identified (Nix-Hodes \& Heybach, 2014). Because of various risk factors, lack of 
awareness, and need for assistance, homeless education liaisons and their training are essential for encouraging homeless student academic success. By understanding student homelessness, liaisons will be better equipped to refer students to appropriate resources and agencies as mandated by ESSA (2015).

\section{Methods}

For this study, a qualitative case study design was utilized to explore how homeless education liaisons use training and community resources to support the academic success of homeless students.

\subsection{Participants}

Table 1. Participant Information

\begin{tabular}{|c|c|c|c|c|c|}
\hline Pseudonym & $\begin{array}{l}\text { District } \\
\text { Type }\end{array}$ & $\begin{array}{l}\text { Affected } \\
\text { Students }\end{array}$ & Education Level & $\begin{array}{l}\text { Time as } \\
\text { Liaison }\end{array}$ & $\begin{array}{l}\text { Time from } \\
\text { Retirement }\end{array}$ \\
\hline Reagan & $\begin{array}{l}\text { City, } \\
\text { small }\end{array}$ & 116 & Educational Specialist & Two years & $10+$ years \\
\hline Leslie & $\begin{array}{l}\text { Rural, } \\
\text { fringe }\end{array}$ & 219 & Educational Specialist & Six years & $10+$ years \\
\hline Peyton & $\begin{array}{l}\text { Suburb, } \\
\text { large }\end{array}$ & 1,325 & Master's Degree & Nine years & $10+$ years \\
\hline Avery & $\begin{array}{l}\text { City, } \\
\text { small }\end{array}$ & 179 & Bachelor's plus & $\begin{array}{l}\text { Seven } \\
\text { years }\end{array}$ & 1.5 years \\
\hline Bailey & $\begin{array}{l}\text { Rural, } \\
\text { distant }\end{array}$ & 119 & $\begin{array}{l}\text { Post Master's in Educational } \\
\text { Leadership }\end{array}$ & 18 months & $10+$ years \\
\hline Cameron & $\begin{array}{l}\text { Rural, } \\
\text { fringe }\end{array}$ & 111 & Masters of Social Work & $\begin{array}{l}\text { Seven } \\
\text { years }\end{array}$ & $10+$ years \\
\hline Devin & $\begin{array}{l}\text { City, } \\
\text { middle }\end{array}$ & 632 & $\begin{array}{l}\text { Masters of Social Work and } \\
\text { Administration }\end{array}$ & 20 years & 5 years \\
\hline Harley & $\begin{array}{l}\text { City, } \\
\text { middle }\end{array}$ & 189 & Master's plus 30 & 17 years & Whenever \\
\hline Jordan & $\begin{array}{l}\text { Rural, } \\
\text { fringe }\end{array}$ & 357 & Masters of Education & 3 years & $>2$ years \\
\hline $\begin{array}{l}\text { Morgan, Social } \\
\text { Worker }\end{array}$ & $\begin{array}{l}\text { Rural, } \\
\text { fringe }\end{array}$ & 357 & Bachelor's & 3 years & $10+$ years \\
\hline Toni & $\begin{array}{l}\text { Rural, } \\
\text { remote }\end{array}$ & 207 & Ph. D & 2 years & 2 years \\
\hline Kim & $\begin{array}{l}\text { Suburb, } \\
\text { small }\end{array}$ & 163 & Masters of Social Work & 3 years & $10+$ years \\
\hline Skylar & $\begin{array}{l}\text { Rural, } \\
\text { fringe }\end{array}$ & 194 & Master's & 3 years & $10+$ years \\
\hline Casey & $\begin{array}{l}\text { Suburb, } \\
\text { large }\end{array}$ & 521 & Ph. D & 5 years & Retired \\
\hline Wesley & $\begin{array}{l}\text { Suburb, } \\
\text { large }\end{array}$ & 237 & Ed. D. & 5 months & $10+$ years \\
\hline
\end{tabular}

Participants in this study consisted of 15 local homeless education liaisons recruited from school divisions in Virginia that had more than 100 students experiencing homelessness 
during the 2014-2015 academic year. Each participant served or is currently serving students experiencing homelessness within Virginia. Of the 15 participants, nine had between one and five years experience as an educational liaison, four had between six and 10 years experience as an educational liaison, and two had over 10 years experience as an educational liaison (see Table 1).

\subsection{Data Collection and Analysis}

The key questions that guided the qualitative descriptive case study were:

R1. What training and resources do liaisons in Virginia receive to encourage the academic success of homeless students?

R2. How do local homeless education liaisons perceive and use their training and community networks as well as resources to encourage the academic success of homeless students?

R3. What are challenges liaisons encounter in using their training in dealing with homeless students? How can challenges be overcome?

To collect information to answer the research questions, semi-structured interviews were conducted with participants to gain information on local homeless education liaisons and their training as tools to ensure academic success for students experiencing homelessness. The goal of interviews was to explore the role of liaisons and how they applied their training to assist homeless students. Settings where liaisons fulfilled their professional responsibilities were explored and understanding what type of advice seasoned liaisons would pass on to new professionals was sought.

Participants were asked open-ended questions in a semi-structured, face-to-face, or over-the-telephone format. Data were obtained to understand the role of liaisons and their training as tools to ensure the academic success for homeless students. After obtaining appropriate informed consent documentation, audio recordings and field notes were used for each interview. Pseudonyms were assigned to participants to protect identities and maintain participant confidentiality. Data from interviews were compared to data provided in liaison training documents to determine themes and ensure consistency. An audio transcription service was used to transcribe interviews, and manual coding was conducted prior to putting the data into NVivo 11 software for data analysis.

NVivo 11 software was used to analyze data collected from participants. Interview transcripts from participants, which a transcription agency transcribed, were uploaded to capture trends and establish coding using nodes within the software program. Manual coding was used to identify themes. Transcripts were manually coded to simplify the processes of coding within NVivo 11.

Van Manen's six activities of research, which are dynamic and not necessarily sequential, were applied to data analysis (Hein \& Austin, 2001). Although a case study was conducted, the framework provided an organized, yet cyclical approach for data analysis. According to Hein \& Austin (2001), step one "turning with commitment to an abiding concern" allowed specific focus on liaisons and their training. Step two was to explore the lived experience 
through the data collection and interview process, was used (Hein \& Austin, 2001). Step three was the categorizing of data through implementing holistic and selective highlighting and identification processes (Hein \& Austin, 2001). Transcribed texts were read several times to gain a holistic understanding of data. Initial themes were identified and developed by highlighting and selecting recurring or related words, sentences, phrases, or chunks of dialogue in addition to using NVivo 11 to generate word clouds to determine words appearing most frequently.

Step four was to describe the phenomenon using the written word, through discussing initial discoveries and reviewing trends to determine and establish themes based upon interview data (Hein \& Austin, 2001). A strong stance toward research questions, which is step five, was maintained by studying emerging themes using research questions as a guide to ensure themes maintained consistency (Hein \& Austin, 2001). Step six, which is balancing the research context by considering data in their totality, by comparing themes, data organized by study participants, data organized by interview questions, and data as collected from training documents to clarify coding, was also incorporated (Hein \& Austin, 2001).

\section{Results}

During data analysis several major themes were discovered: local homeless education liaisons address needs of students experiencing homelessness, using training and community resources; local homeless education liaisons have challenges because of the influence of other roles or a lack of training in specific areas to most effectively serve homeless students; participating liaisons seek additional training regarding networking with other liaisons as well as addressing changes to the McKinney-Vento Homeless Assistance Act based upon Every Student Succeeds Act; and, reflections, including what liaisons wish they had known when they started as well as advice for new liaisons.

\subsection{The Role of a Homeless Education Liaison}

Exposure to situations liaisons encountered paints an explanation why they are important to the students they serve. The following are situations where local homeless education liaisons and other public education professionals, united to raise a child.

I had some students moving to a hotel that was probably inadequate. I helped that student, the parent, mom and a little preschooler, a four-year-old, go to the school to help with paperwork ... made an appointment at the Health Department for the parent, arranged transportation so the kid would have medical records for the future immunization records and things in case they leave our school division (Cameron).

We had a family with a student who had a lot of behavioral issues ... We did not know until approximately a few weeks in that they were living in a tent, that they were homeless. ... Our social workers jumped in to action. Helped the family with vouchers. Getting housing, doctors, and reaching out to relatives who could help (Reagan).

Harley helped a high schooler who was kicked out of his parents' house because of his sexual orientation. She shared: 


\section{NI Macrothink}

Journal of Education and Training

ISSN 2330-9709

He went into the shelter ... didn't have any resources. He [had just] turned 18...didn't have money; he was finishing up his Cosmetology course, [but] he didn't have money to buy what's called a kit [as a part of his certification requirement]. We had to go get a kit for him. I worked with him to help with his placement because when he was 18, he wasn't allowed in the family shelter, but the single man shelter ... so I worked a lot under housing [and] with trying to get counseling [to] get people to help support him being on his own.

Scenarios like ones above are just a few experiences liaisons may encounter while advocating for students experiencing homelessness. Liaisons encounter scenarios that are considerably more difficult emotionally and resource-wise because of what students and families go through. Student homelessness spans the age spectrum of individuals served by public education, making local homeless education liaisons, their role, and their training crucial to the academic success of that student population. Regarding liaison responsibilities for the homeless student population in Virginia, Reagan summed up:

The biggest thing for me is working with our schools to ensure that we're providing families the appropriate education [for the] homeless and ensuring that we are providing the services. ... to ensure that we're offering families some stability, especially with schooling and no interruption in instruction if possible.

\subsubsection{Liaison Responsibilities}

Understanding liaison responsibilities through their eyes is important to understanding how they perceive their roles, training, community networks, and resources. Cameron stated the responsibility of local homeless education liaisons is "to protect the rights of students who are experiencing homelessness." To protect rights of homeless students, liaisons must identify students within the demographic. Avery stated,

As the local homeless liaison, I protect the rights of the individual students who become homeless, and I help to identify those students. I offer services to the students and to the families in terms of the things I'm required to offer, such as free lunch, school supplies, but I also meet with the families and help them design a housing plan. I keep up with the resources in the area so that I can help them.

Regarding responsibilities in a Virginia division, Harley added, "We follow what the law requires us to do. Then we add some other things; we add some other services that are used to support the children. ... I act as an advocate, outreach, and then direct service."

Liaison responsibilities cover a variety of age groups and programs across Virginia, including training others within school divisions. Bailey explained:

I matchup siblings and whatnot for anyone in other grade levels. We work collaboratively as far as that goes. Then my responsibilities would be for all the other K-12 students ... it is all encompassing. It is training our boots on the ground our counselors and social workers and registrars.

Ensuring school district professionals keep the best interest of students experiencing 
homelessness at the forefront of decisions is important. Popp provided additional information regarding the responsibilities of local homeless education liaisons:

They are identifying children who are experiencing homelessness, and ways that they do that include professional development and making staff in the schools aware of what these children need and who they are as well as doing that within the community. It's making sure that the policies, procedures within the school don't act as barriers to these children accessing what they need in school. It's making sure that they are getting their immediate enrollment in school and that they are maintaining the school of origin, so having those processes in place.

Whether through grants or community networks, liaisons also develop or oversee programs within their divisions. The purpose of programs is to address needs students have using available resources. Liaisons oversee programs such as diaper banks, providing breakfast, and babysitting services. Devin said, "We actually have a diaper bank in our building as well so we try to touch on clothing, diapers, food." There are also programs in place to assist students and their families with mentoring, babysitting, and tutoring. Kim mentioned, "Adults will sign up with the school, and they'll be assigned a child. Then they can come and eat breakfast with them in the mornings. It's something special for the kids they look forward to. They get to eat breakfast with their buddy ... at least once a week."

Avery developed Sprout, a program through a partnership with a local university:

Any of the children who are not going to school are seen by graduate students from the speech pathology department. Their development is checked, and the families are presented with some games and books that are age appropriate for that child. [Graduate students] agree to meet with the people periodically to do a development checkup.

Morgan described a graduation ceremony within a Virginia division that liaisons designed specifically for unaccompanied youth, who may not have family willing or able to celebrate the academic milestone with them, She said, "We do a graduation ... a celebration for our unaccompanied minors. The [local] hospital plans it for us. All we gotta do is just send out the invitations. That's when I have to talk it up to the students, like, "Come on, let's go."

\subsection{Community Resources Available to Education Liaisons}

Community networks and resources used by liaisons are essential to helping homeless students, and networks as well as resources vary significantly depending on districts and what is surrounding them. Variations of community resource usage exist based upon a school division structure.

We are networked with a number of resources in the community, from our food pantries, to our shelters, to other various team of care members. Other providers of services, like our infant and toddler connection network, or Head Start programs, or other preschool programs. We try to be as available and open to, and aware of the resources out there, so that we can direct people appropriately (Peyton).

I started something where all the folks that are homeless can get their hair cut and their 


\section{Macrothink}

nails done, and all this stuff for free at it's called the Career Center, the Cosmetology Department ... These women, men and the children don't have money to get their hair cut. Let me see if I can get the students who are learning how to cut hair to help these children, and their mothers, and fathers (Harley).

I refer them to both the emergency assistance fund as well as to the rapid rehousing if appropriate. If they're doubled up, then they appropriately get referred ... We have some churches that will also help ... I try to use them only as a last resort, because they don't have that many resources, and I like for them to be there when I really need them (Avery).

Bailey described what happens in a school division that is limited on materials to help students experiencing homelessness:

We just don't have the resources in our community. We don't have doctors. We have two dentists, but we don't have an urgent care. Our health department is extremely limited in what they provide ... Very limited low income housing opportunities, no public transportation. The resources ... are extremely limited.

Popp empathized with liaisons in communities with limited resources and advocates for liaisons in such divisions. Popp shared what it looks like when attending different partnership meetings, "when I sit in one of those state partnership meetings and say, 'You want us to connect with the mainstream resources. There aren't any for these children!' And they just don't hear me."

Through using community networks, eight out of 15 local homeless education liaisons pulled resources together in an easily accessible format for students and families experiencing homelessness in their divisions.

I prepared a booklet for the families. I have a parent resource package that I put together that has the agencies, emergency shelters. It has the forms for you to check your credit. I usually give them the list of openings for section 8 housing. It has a list of apartments in the lower income range (Avery).

Peyton's district has resources based upon different segments of homeless student populations.

We have brochures that are developed and available for different populations. We have one for staff members. We have one for unaccompanied youths, and we have one for parents and guardians. Basically, it's to give them an overview of McKinney, and also to give them a snapshot of resources, with phone numbers, contact information, that they could use (Peyton).

Toni uses resources from Project Hope to assist homeless students and families within a Virginia school district, "We make sure that the information on homeless that comes from Project Hope every year, that updated information is put in our schools in an area where the staff has opportunities to see the new information."

\subsection{Training for Homeless Educational Liaisons}


Participating local homeless education liaisons were trained for their position in several ways. Twelve out of 15 said they were trained informally, while 14 out of 15 cited formal training. Twelve out of 15 liaisons credited on the job training. Avery mentioned, "A lot of the training is self-training. There's a lot that is written that can be helpful if you're willing to read it." Bailey added, "Ninety-nine percent has been on the job training. I just had to figure it out." Peyton shared that,

On-the-job training is just sitting and answering the phone every day, and understanding what's going on with our schools, and trying to figure out a way in which to be sure that we are either developing, or offering the tools necessary to assist them in doing their job (Peyton).

Nine of the 15 indicated the training covered recent changes to the McKinney-Vento Homeless Assistance Act.

Updating the law, or learning about the updates in the law, learning about the specifics, getting into the nitty gritty of the law and how it's applied to the children and to the families, very, very helpful. Then our state meetings, our state and regional meetings are extremely helpful because we know what's going on in our state, in Virginia (Harley).

We talked about the ESSA changes with homelessness; we talked about why a child becomes homeless due to flood, fire, tornado, or natural disaster. We talked about access, how that is two words, access, attendance and success. We talked about the grants that are available (Leslie).

\subsection{Training Needed by Homeless Educational Liaisons}

Participating liaisons presented areas they feel they could use more training to serve students better because of various issues.

With the upcoming changes, I'm sure there will be, probably efficiencies that can be learned, or as we move forward and develop best practices, with these new requirements, there could be learnings that come from that, that we would definitely, that I would benefit from to know and be sure that we're operating in as efficient manner as possible. I think the issue for us, is capacity, and dealing with the volume of work, and trying to be as efficient as possible, and making sure that we're serving everyone, in a relatively quick time frame (Peyton).

The new laws that just went into effect October 1st where we have to transport children who are permanently housed. I still have some questions about how our counties are handling that. I wish I could get together with other counties and find out whether I'm doing it the same way they are and whether they're handling it any differently (Avery).

If we didn't have all the support that we have from the state office, we would probably need to get together with other liaisons twice a year or something. Because you almost can't plan for what's coming. You almost can't have a bank of information in your head to pull from because each situation you have to pull from is unique (Jordan).

I've been working with my advisory board to revise and redo our best interest 
determinations, written explanation and dispute process. So, I just know with these expanded definitions and requirements, there's going to be more need to document how we're making those decisions with families. And recognizing we're probably going to see more disputes. So, I really think once I get this approved through the channels that be, getting that training to liaisons so they know what the process needs to be, so they're in compliance with the law and they've really thought through how to do it appropriately (Popp).

\subsubsection{Suggestions for Improving Training}

Liaisons suggested ways to improve training, including a need for more frequent training, more localized sessions, opening training up to other school professionals, and more case study based training. There were also suggestions for more support for liaisons in the forms of chat rooms or message boards that would allow them to share experience and ask questions. Most participants in the study felt better networking and communication with other liaisons would be essential to their success in aiding students experiencing homelessness.

I think it would be really cool if all the liaisons in Virginia, or at least half the state could get together and have time to really talk about their programs, and we can learn from each other, more than just a local area ... When we get together as a state or part of the state, and a region, we have a little bit of time but not much time. I think we can learn a lot from each other, and from our experiences (Harley).

Jordan drew on previous experience as a homebound coordinator to provide a suggestion for improving training for local homeless education liaisons:

Years ago, the homebound coordinator in Richmond had a group set up, and if anybody had a homebound question you could send it to her, and she would send it out to everybody. You would get a response back from a bunch of different school districts. That was pretty useful. I found out about online programs and different things by hearing from that group.

Peyton added, "I think just as time rushes on, and as there is awareness of best practices, or better ways to do things, I think the more broadly we share that knowledge, the potential is there then for all of us to increase our efficiency and effectiveness."

\subsection{Challenges Faced by Homeless Educational Liaisons}

Thirteen of 15 participating local homeless education liaisons had collateral duties that could potentially interfere with the liaisons' ability to fulfill their professional liaison obligations without interruption. Two liaisons were without collateral duties, and one liaison did not have local homeless education liaison within the job description. Four participating liaisons stated their collateral duties complemented the liaison position. Five participating liaisons stated the collateral duties complemented and conflicted with the liaison position merely because of time constraints. Leslie, who works with nine elementary schools has to juggle responsibilities:

I'm elementary/middle school supervisor director. I am director of curriculum and instruction. Our HR person retired, so now I do HR. Well, I just about do everything but finance ... I do federal programs ... I believe the homeless liaison position has taken on 
more time and effort to case manage some of those kids. Therefore, that might be the detriment because sometimes it takes up a lot more time to be able to spend more quality time on my other part of my job. That is probably where the conflict would be.

Homeless families often times needed the services of the specialized social workers. They had the mental health needs that we would like to prevent and help the kids when they get into their schools. It's really important to be a liaison and know all about the links to the community services that I was providing and the school was providing (Casey).

\section{Discussion}

Local homeless education liaisons work diligently to address needs of students experiencing homelessness within their communities. They are responsible for establishing community partnerships with people and organizations that could address basic needs for homeless students and their families. Participants believe training and communities are necessary tools in encouraging homeless students to achieve academic success. Even liaisons from school districts with limited sources value communities and people within who help take care of homeless students. Participants discussed how they could not meet responsibilities of their position without the strong team surrounding them.

Training and community networks are vital for assisting students experiencing homelessness. Participants felt thankful for the variety of organizations whose members step in to help students, including private donors, doctors, dentists, churches, or other groups. Community members and organizations allow liaisons to meet basic needs of homeless students and their families, making it easier for students to focus on learning (Maslow, 2013). Without organizations and groups providing food, shelter, and clothing, students experiencing homelessness would not focus on learning because survival would be their priority (Maslow, 2013). Some participants said they had to beg, borrow, and steal to meet needs of students under their purview, so liaisons greatly appreciate volunteers and donors, who help care for students.

Local homeless education liaisons appear to be unsung heroes in the academic realm of students experiencing homelessness. Despite collateral duties, liaisons work hard because "it's all about the kids." Liaisons demonstrate compassion and common sense along with a working knowledge of the McKinney-Vento Homeless Assistance Act, which several liaisons stated they needed to know "like the back of their hand." Possessing a strong knowledge of communities and resources provides liaisons with tools to assist the unique student population. In communities with limited material resources, liaisons indicate teachers and counselors are often their eyes, ears, hands, and feet when caring for homeless students and youth. Without awareness and compassion, local homeless education liaisons would experience stunted professional capacities.

Local homeless education liaisons receive most of their training through self-study or experience (Teaching Excellence in Adult Literacy, 2011). Liaisons also have access to formal training, which occurs through seminars, and nonformal training, which often occurs when corresponding with the state coordinator. Learning methods used by liaisons further support adult learning theory because in today's knowledge economy, liaisons need to obtain 
professional knowledge through nontraditional ways (Merriam \& Bierema, 2014). Liaisons indicated they wished they had known how much time the position required and that they had acquired a mentor early in their liaison career.

Experienced liaisons recognized the value of adult learning and advised new liaisons accordingly. Liaisons indicated the importance of self-study because many are isolated practitioners. Participants indicated self-study was essential to remaining updated on the McKinney-Vento Homeless Assistance Act and other legislation that governs the position. In adult learning theory, self-guided learning is essential because adults have a necessity to learn for self-improvement, especially in professional capacities (Merriam \& Bierema, 2014). Self-guided learning is also problem based, which based upon participant responses is accurate as many sought information because of certain situations (Teaching Excellence in Adult Literacy, 2011). For liaisons, a big part of learning is nonformal because of the need to learn about and understand their communities and resources (Merriam \& Bierema, 2014). Through hindsight and foresight, adult learning theory could assist local homeless education liaisons as they strive to understand and implement best practices for assisting students experiencing homelessness.

\section{Research Limitations}

A main limitation of this study is that the participants were limited to 15 local homeless education liaisons within Virginia. Therefore, generalizing the results of this study to other school districts may be limited. Views and experiences reported in the findings were limited to experiences and communities of participating liaisons. Views of students or families experiencing homelessness were not collected in this study.

\section{Recommendations}

Findings of this study should assist educational leadership with understanding the role and importance of local homeless education liaisons and their training as tools toward encouraging the academic success of students experiencing homelessness. Views and experiences of participating liaisons provide insight to help division-level leadership understand the function of liaisons as well as empathize with their responsibilities. This is not to say liaisons are incapable, but with changes in legislation, the workload for liaisons will increase. As this study found, training influences liaisons' ability to meet mandates of the position. The combination of learning new laws and how to implement them along with pre-existing collateral duties outside of the liaison umbrella make it difficult to address needs of homeless students, especially in divisions with higher homeless student populations.

Several participants expressed concern regarding the liaison workload when aligned to the annual pay schedule, which indicates the timeframe used to determine individual salaries. Some mentioned frustration because of time constraints and how long arranging appropriate and required academic services for students experiencing homelessness takes. Other participants were concerned about law changes because they did not want to disappoint students or receive consequences for failing to follow mandated changes. The state coordinator is in the process of updating training requirements under ESSA; however, liaisons require time to participate in training to adjust their practices. Additionally, the state 
coordinator is creating resources that will allow liaisons to train other employees within school divisions, especially considering new mandates require training for education professional who works with homeless students. Once training updates are in place, results of monitoring the academic success of students experiencing homelessness should continue to demonstrate growth in percentages of students reaching academic milestones such as graduation.

Educational leaders must understand how legislative changes have redefined roles of local homeless education liaisons (ESSA, 2015). Without understanding liaisons' new responsibilities, there is not likely a way liaisons will be able to function in the professional capacity without hindrance from other responsibilities. With ESSA (2015) revisions, liaisons are responsible for training more people within their school districts, coordinating expenses for transportation across division lines, as well as ensuring students have access to schools that are in students' best interests. Coordinating transportation alone consumes a great deal of time. With new guidelines regarding school of origin or best interest for students, these processes will take longer than in the past. To support liaisons effectively, leadership must understand what requirements are and if necessary make appropriate budget adjustments, especially in divisions with a larger percentage of homeless students. Insights from the current study can help educational leadership more effectively incorporate local homeless education liaisons and their training into division plans that should ensure every student has an equal opportunity to succeed.

With research indicating the importance of local homeless education liaisons, including the expansion of responsibilities (ESSA, 2015; Pavlakis, 2014; Petersburg, 2010; Sulkowski \& Joyce-Beaulieu, 2014), educational leadership could use this information to enhance work environments for liaisons. Perhaps such improvements would include providing time and resources for liaisons to attend training or write grants to provide more resources to homeless students. Suggested changes would include training others within school districts to understand local homeless education liaisons and how to allow them to assist homeless students more effectively. School division leadership must ensure each person who works with homeless students attends McKinney-Vento training. If school district leadership allowed liaisons to focus more on liaison responsibilities without the pull of collateral duties, it would be easier to provide such training to district-level personal. Remembering students are people first is imperative to ensuring their success. If school-division leadership develops an appropriate understanding of local homeless education liaisons and their responsibilities, then perhaps, students experiencing homelessness could more readily receive academic supports to which they are entitled. This would improve homeless students' chances of obtaining academic success because district-level leadership allowed liaisons to do their job.

\section{Conclusions}

The role of local homeless education liaisons and their perceptions and use of training and community networks varies between school divisions and individuals. Liaisons are an essential link, allowing students who lack stability in their personal lives to experience at least some degree of normalcy and consistency in their academic journeys. Gaining insight into how liaisons are trained as well as how they perceive and use their training and resources 
allows us to see that liaisons are hard workers, who seem to genuinely care for student populations they serve. The insights gained in this study support the need to explore how district-level leadership incorporates local homeless education liaisons into their vision for student success. Liaisons are typically satisfied with their training despite needing guidance on the implementation of new legislation. Studying the role of liaisons and their training within school districts provides a rationale to extend research on leadership and their knowledge as well as their incorporation of liaisons. The more leadership understands liaisons and their responsibilities, the more effectively districts can assist homeless students. Gaining a deeper understanding regarding local homeless education liaisons and how they encourage the academic success of students experiencing homelessness is significant step toward possibly ending student homelessness.

\section{References}

Aviles de Bradley, A. M. (2008). Educational rights of homeless children and youth: Legal and community advocacy. American Educational History Journal, 35(2), 261-277.

Aviles de Bradley, A. M. (2011). Unaccompanied homeless youth: Intersections of homeless, school experiences, and educational policy. Child \& Youth Services, 155-172.

Edidin, J. P., Ganim, Z., Hunter, S. J., \& Karnik, N. S. (2012). The mental and physical health of homeless youth: A literature review. Child Psychiatry and Human Development, 43(3), 354-375.

Every Student Succeeds Act [ESSA] of 2015, 114, Stat. 1177. (2015).

Harper, F. D., Harper, J. A., \& Stills, A. B. (2003). Counseling children in crisis based on Maslow's hierarchy of basic needs. International Journal for the Advancement of Counselling, 25(1), 11-25.

Hein, S. F., \& Austin, W. J. (2001). Empirical and hermeneutic approaches to phenomenological research in psychology: A comparison. Psychological Methods, 6(1), 3-17. Retrieved from https://search.proquest.com/docview/614416389?accountid=166133

Hendricks, G. E., \& Barkley, W. M. (2011, September). The academic effect of homelessness: An important role for school social workers. School Social Work Journal, 36(1), 79-94.

Jozefowicz-Simbeni, D., \& Israel, N. (2006, January). Services to homeless students and families: The McKinney-Vento Act and its implications for school social work practice. Children \& Schools, 28(1), 37-44.

Kislyakov, P. A., Shmeleva, E. A., Karaseva, T. V., \& Silaeva, O. A. (2014). Monitoring of education environment according to the social-psychological safety criterion. Asian Social Science, 10(17), 285-291. Retrieved from http://search.proquest.com/docview/1613116537? accountid=458

Maslow, A. H. (2013). A theory of human motivation. Mansfield Centre, CT: Martino Publishing. 
Masten, A. S., Fiat, A. E., Labella, M. H., \& Strack, R. A. (2015). Educating homeless and highly mobile students: Implications of research on risk and resilience. School Psychology Review, 44(3), 315-330.

McKinney-Vento Act. (2001). Retrieved from http://www2.ed.gov/policy/elsec/leg/esea02/pg116.html

Merriam, S. B., \& Bierema, L. L. (2014). Adult learning: Linking theory and practice. San Francisco, CA: Jossey-Bass.

Miller, P. M. (2011a). An examination of the McKinney-Vento Act and its influence on the homeless education situation. Educational Policy, 25(3), 424-450.

Miller, P. M. (2011b). Homeless families' education networks: An examination of access and mobilization. Educational Administration Quarterly, 47(4), 543-581.

Murphy, J. F., \& Tobin, K. J. (2011, November). How homeless children and youths can succeed. Poverty and Learning, 32-37.

National Center for Homeless Education (NCHE). (2013). Homeless liaison toolkit: 2013 edition. Retrieved from http://center.serve.org/nche/downloads/toolkit2/toolkit.pdf

National Center for Homeless Education (NCHE). (2015). Federal data summary school years 2011-12 to 2013-14. Retrieved from http://center.serve.org/nche/downloads/data-comp-1112-1314.pdf

Nix-Hodes, P., \& Heybach, L. M. (2014). Removing barriers: The struggle to ensure educational rights for students experiencing homelessness. Critical Questions in Education, 5(3), 143-171.

Pavlakis, A. E. (2014). Living and learning at the intersection: Student homelessness and complex policy environments. The Urban Review, 46(3), 445-475.

Petersburg, B. (2010). Reconciling the McKinney-Vento Act with the vision of the universal declaration of human rights: Improving local educational agency liaisons' ability to serve America's homeless children. Journal of Public Law \& Policy, 30, 447-484.

Project HOPE-Virginia. (2015). Retrieved from http://education.wm.edu/centers/hope/

Rafferty, Y., \& Shinn, M. (1991, November). The impact of homelessness on children. American Psychologist, 46(11), 1170-1179.

Sulkowski, M. L., \& Joyce-Beaulieu, D. (2014). School-based service delivery for homeless students: Relevant laws and overcoming access barriers. American Journal of Orthopsychiatry, 4(6), 711-719.

Teaching Excellence in Adult Literacy. (2011). Retrieved from https://teal.ed.gov/sites/default/files/Fact-Sheets/11_\%20TEAL_Adult_Learning_Theory. pdf

U.S. Department of Education. (2015). Education for homeless children and youth (EHCY) 
http://center.serve.org/nche/downloads/ehcy_profile.pdf

U.S. Department of Education. (n. d.). National Center for Homeless Education. Retrieved from http://center.serve.org/nche/

William and Mary School of Education. (2016). Project-HOPE Virginia: Education for homeless children and youth. Retrieved from http://education.wm.edu/centers/hope/

\section{Copyright Disclaimer}

Copyright reserved by the author(s).

This article is an open-access article distributed under the terms and conditions of the Creative Commons Attribution license (http://creativecommons.org/licenses/by/3.0/). 